Reprinted from: Weed Technology, April-June 1994. 8(2):285-288.

Published by: Weed Science Society of America. http://www.wssa.net

\title{
Effect of herbicide treatment on leafy spurge gall midge (Spurgia esulae) population
}

\author{
RODNEY G. LYM and ROBERT B. CARLSON \\ The authors are Prof., Crop and Weed Sci. Dep. and Entomology Dep., respectively, North Dakota State Univ., Fargo, \\ ND 58105 .
}

\begin{abstract}
The Spurgia esulae gall midge was introduced in North Dakota in 1986 as a biocontrol agent for leafy spurge. Spurgia esulae causes stem tip galls (PHOTO) thereby decreasing seed production and it has been most successful near wooded areas. However, a second control method is needed to reduce the leafy spurge infestation and prevent spread from roots. Imazethapyr, 2,4-D, or picloram application did reduce the number of $S$. esulae galls but not the number of larvae per gall. Long-term $S$. esulae population was not affected by herbicide application. The integration of herbicides with $S$. esulae would prevent leafy spurge spread from a wooded area and would reduce seed production within an area where herbicides generally cannot be used.
\end{abstract}

\section{Nomenclature:}

Imazethapyr, 2- [4,5-dihydro-4-methyl-4- (1-methylethyl) -5oxo-1H-imidazol-2-yl] -5-ethyl-3-pyridinecarboxylic acid; picloram, 4-amino-3,5,6trichloro-2-pyfidinecarboxylic acid; 2,4-D, (2,4-dichlorophenoxy) acetic acid; leafy spurge gall midge, Spurgia esulae Gagné; leafy spurge, Euphorbia esula L. \#² EPHES.

\section{Additional index words:}

Biological control, integrated management, weed Biocontrol, imazethapyr, piclroam, 2,4-D, EPHES.

\footnotetext{
${ }^{1}$ Received for publication Nov. 29, 1993 and in revised form Feb. 28, 1994. Published with approval of the Director, Agric. Exp. Stn., North Dakota State Univ. as J. Art. No. 2146.

${ }^{2}$ Letters following this \# symbol are a WSSA-approved computer code from Composite List of Weeds, Revised 1989. Available from WSSA, 1508 West University Ave., Champaign, IL 61821-3133.
} 


\section{Introduction}

Successful introduction of non-native insects for leafy spurge biocontrol has been a research goal for many years. The leafy spurge hawkmoth (Hyles euphorbiae L.) was released as early as 1966 in Montana (9). However, leafy spurge hawkmoth populations generally have not survived and when they do, provide control too late in the season to be useful (6). Subsequently, several other insect species for leafy spurge control were introduced from Europe to North America in the mid-1980s (2). These introduced biocontrol insects feed on different parts of the leafy spurge plant and one or more should be capable of establishing within the varied environments where leafy spurge is found.

The stem-boring weevil Oberea erythrocephala (Shrank.) (Coleoptera: Cerambycidae) was introduced in North Dakota in 1985 and was the first leafy spurge biocontrol insect to become established (6). The leafy spurge gall midge Spurgia esulae was introduced in 1986 and increased in population much faster than O. erythrocephala. Spurgia esulae was redistributed in several areas of the state beginning in 1989. The larvae of this European gall midge cause meristem tip gall, which prevent flowering, therefore seed production (8) (Figure 1). The first galls form in late May to early June in North Dakota and continue to establish on new plant growth until early October. There are at least three generations per year (7). Mature larvae overwinter in the soil.

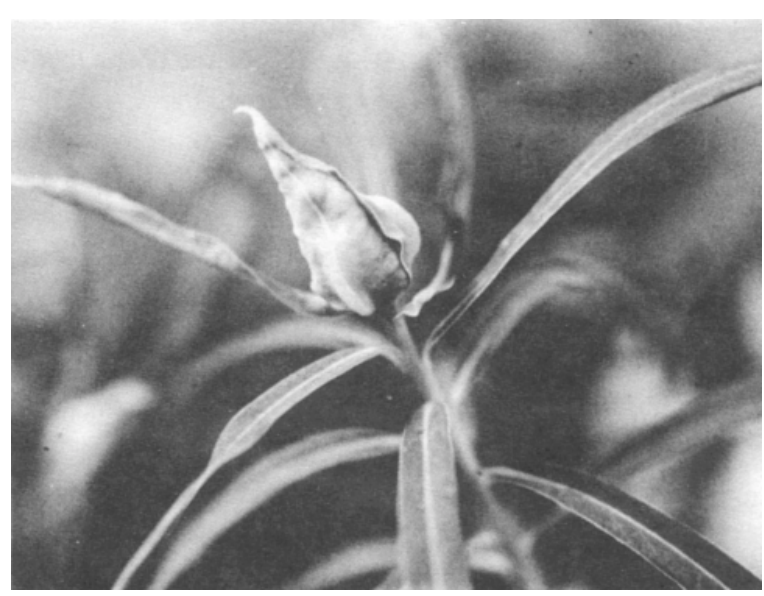

Figure 1. Leafy spurge stem tip galled by Spurgia esulae larvae.

Spurgia esulae has established in several areas of North Dakota and has reproduced most successfully when released in wooded areas or near shelterbelts (2). Spurgia esulae controls leafy spurge by preventing galled stems from flowering, thereby decreasing seed production (8). The main growing tip of an infested plant is often killed by the feeding larvae, which eliminates apical dominance so secondary shoots are produced $(8,10)$. The secondary shoots are attacked by subsequent $S$. esulae generations.

Spurgia esulae, although widely distributed, generally only infests a portion of a leafy spurge infestation so seed production is reduced, but not eliminated. A second control method is needed to reduce the original infestation and prevent spread by roots and seeds of plants not galled. 2,4-D applied alone or with low rates of picloram may be useful in conjunction with $S$. esulae for leafy spurge control near trees. The herbicide 2,4-D is often used near trees to control leafy spurge and can be combined with low rates of picloram for longer-term control when the treatment is applied a safe distance from tree roots (5). Imazethapyr also may be useful because it controls leafy spurge root growth with minor foliage injury and may allow one generation or more of gall production during the growing season of treatment $(3$, 
$4,12)$. The purpose of this research was to determine the compatibility of $S$. esulae with several herbicides in an integrated leafy spurge management program.

\section{Materials and methods}

An experiment to evaluate the effect of various herbicides on $S$. esulae was established within a leafy spurge biocontrol insectary near Valley City, ND in 1991. Spurgia esulae was released at the site in 1986, was well established, and was found scattered throughout the 65-ha location. A 1.5-ha area between two shelterbelts and near the original release site which contained the most dense $S$. esulae population was allocated for the herbicide interaction experiment.

The experiment was in a randomized complete block with three replications and was conducted four times, twice each in 1991 and 1992. The treatments, 2,4-D, imazethapyr, and picloram plus 2,4-D were applied when leafy spurge was in the true flower to early seed-set growth stage, which is the most effective application timing for picloram or picloram plus 2,4-D (5). This timing corresponded to the first and second S. esulae generation which was approximately June 1 and June 21, respectively, both in 1991 and 1992. Herbicides were applied in water using a hand-held sprayer delivering $75 \mathrm{~L} / \mathrm{ha}$ at $240 \mathrm{kPa}$. Each replication of the experiment was 6- by 6-m square and was divided into four 3- by 3 -m plots (Figure 2). Thus, $75 \%$ of the replication was treated with herbicide. A 1.8 - by 1.8 - by $1.8-\mathrm{m}$ cage was placed in the center of each replication. The cage was covered with netting ( 0.1 by $0.1 \mathrm{~mm}$ mesh) to prevent $S$. esulae movement inside or outside of the caged plot area and affecting gall density.

The effect of the herbicide treatment on $S$. esulae population was determined by monitoring both gall density and the number of larvae per gall. Gall density was determined by counting the number of galls in two $0.6-$ by $0.6-\mathrm{m}^{2}$ quadrats of each treatment within the caged area $0,1,2,4,8,12$, and 52 weeks after treatment (WAT) ${ }^{3}$. The number of larvae per gall was determined by harvesting five galls per treatment from within each plot, but outside the caged area and transporting them to the laboratory for immediate analysis. The harvested galls were taken outside the caged area so that change in population density within the cage only was due to herbicide treatment. Preliminary data indicated the herbicide treatment effect on the number of larvae per gall was the same inside or outside a caged area.

Netting from the cages was removed in late fall after $S$. esulae were dormant to prevent damage to the cage, but the cage frame was left in place. The netting was replaced in early spring the following year prior to $S$. esulae adult emergence so that the population within the caged area was not affected by adult movement from outside the treated area.

Data were analyzed using the general linear models procedure with the protected LSD mean separation technique (11). The four trials had similar variance, so the combined data are presented.

\footnotetext{
${ }^{3}$ Abbreviation: WAT, weeks after treatment.
} 


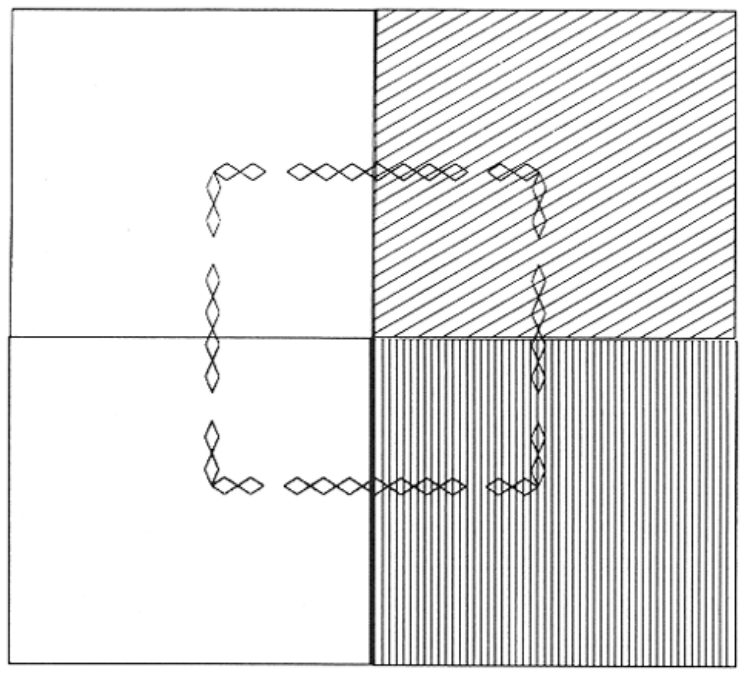

Figure 2. A 6- by 6-m square was divided into four 3- by 3-m plots for each replication of the experiment with a 1.8by 1.8 - by $1.8-m$ cage $(<<><>)$ placed in the center to inhibit $S$. esulae movement inside or outside of caged plot area.

\section{Results and Discussion}

Herbicide applied to leafy spurge did not affect long-term Spurgia esulae population. The number of $S$. esulae galls started to decline immediately following herbicide treatment, and the decline continued until 8 WAT (Table 1). However, by the end of the growing season (12 WAT), the gall population was similar regardless of treatment. The overwintering S. esulae population was not affected by herbicides applied in spring, as the gall density was similar the following growing season (52 WAT) regardless of treatment.

Spurgia esulae began to reestablish galls on 2,4-D-treated plants by 8 WAT, whereas gall reestablishment occurred by 12 WAT with picloram plus 2,4-D (Table 1). 2,4-D at $1.1 \mathrm{~kg} / \mathrm{ha}$ applied in June generally provides leafy spurge top growth control until mid to late August while picloram plus 2,4-D provides near season-long top growth control (4). Thus, S. esulae infested stem tips to induce gall formation soon after leafy spurge regrowth occurred. Although imazethapyr did not readily kill leafy spurge top growth, the weed growth declined rapidly following treatment and the effect on $S$. esulae gall formation was similar to the phenoxy herbicides.

Spurgia esulae gall density in the untreated control generally declined from 29 galls per $\mathrm{m}^{2}$ at the start of the study in 1991 to 16 galls per $\mathrm{m}^{2}$ at completion of the experiments in 1993 (Table 1). This decline was not due to the herbicide treatment but probably to a large increase in a native wasp [(Zatropis nigroaenus Ashmead) Hymenoptera: Pteromalidae] that parasitized the larvae in the S. esulae gall (1). This parasite emerges later in the growing season than $S$. esulae, so it does not affect gall survival until late within the second or third generation. However, once present, this parasite reduces S. esulae larvae survival by $>50 \%$ (6). 
Table 1. Spurgia esulae gall density on leafy spurge as affected by herbicide treatment near Valley City, ND averaged over four S. esulae generations and two growing seasons.

\begin{tabular}{|c|c|c|c|c|c|c|c|c|}
\hline \multirow[b]{2}{*}{ Treatment } & \multirow[b]{2}{*}{ Rate } & \multicolumn{7}{|c|}{ Weeks after treatment } \\
\hline & & 0 & 1 & 2 & 4 & 8 & 12 & 52 \\
\hline & $\mathrm{kg} / \mathrm{ha}$ & \multicolumn{7}{|c|}{ no. galls $/ \mathrm{m}^{2}$} \\
\hline $2,4-\mathrm{D}$ & 1.1 & 27 & 17 & 9 & 4 & 8 & 11 & 16 \\
\hline Picloram + 2,4-D & $0.28+1.1$ & 26 & 23 & 3 & 0.2 & 1 & 8 & 8 \\
\hline Imazethapyr & 0.28 & 27 & 19 & 12 & 1 & 3 & 8 & 11 \\
\hline Untreated & - & 29 & 29 & 27 & 26 & 27 & 15 & 16 \\
\hline $\operatorname{LSD}(0.05)$ & & NS & 8 & 8 & 4 & 5 & NS & NS \\
\hline
\end{tabular}

Although herbicide treatment did reduce the number of $S$. esulae galls, the number of larvae per gall in the few galls that were produced was similar to the untreated control throughout the growing season (Table 2). The only exception occurred 12 WAT when slightly more larvae were found in galls on 2,4-D-treated plants than other treated or nontreated plants. The number of larvae declined from 11 per gall 1 WAT to only one per two galls 12 WAT. The decline was due both to decreased leafy spurge growth during warm, dry weather in July and August and to predation by Z. nigroaenus, which killed all larvae in some galls.

Table 2. Spurgia esulae larvae per gall as affected by herbicide treatment on leafy spurge near Valley City, ND averaged over four S. esulae generations and two growing seasons.

\begin{tabular}{llrrrrrr}
\hline & & \multicolumn{5}{c}{ Weeks after treatment } \\
\cline { 3 - 8 } Treatment & \multicolumn{1}{c}{ Rate } & 1 & 2 & 4 & 8 & 12 & 52 \\
\hline & $\mathrm{kg} / \mathrm{ha}$ & & & & & & \\
& 1.1 & 10 & 6 & 1.4 & 1 & 1.6 & 9 \\
2,4-D & $0.28+1.1$ & 11 & 6 & 0.4 & 3 & 0.2 & 12 \\
Picloram + 2,4-D & 0.28 & 9 & 5 & 1.9 & 3 & 0.3 & 9 \\
Imazethapyr & - & 12 & 6 & 2.6 & 0.5 & 0.5 & 10 \\
Untreated & & $\mathrm{NS}$ & $\mathrm{NS}$ & $\mathrm{NS}$ & $\mathrm{NS}$ & 0.7 & $\mathrm{NS}$ \\
LSD $(0.05)$ & & & & & & &
\end{tabular}

2,4-D-treated plants averaged 1.6 larvae per gall 12 WAT compared to only one larvae per two galls in the control (Table 2). This increase probably was due to the young, vigorous regrowth of leafy spurge which was present within $8 \mathrm{wk}$ following 2,4-D treatment compared to slow stem growth on untreated plants which were mostly dormant during late July and August prior to fall regrowth.

Spurgia esulae would be compatible with herbicide treatment in an integrated leafy spurge management program. The most commonly used herbicides, 2,4-D and picloram, could be applied at the optimum growth stage for leafy spurge control as long as a porion of the area, perhaps 15 to $25 \%$, was left untreated to sustain the insect population. The 
integrated program may be most useful near wooded areas or rough terrain, because herbicide treatment would prevent leafy spurge spread outside the tree area or inaccessible site and $S$. esulae would reduce seed production from within the areas where herbicides generally cannot be used.

\section{Acknowledgments}

The authors thank James Kapaun, Cheryl Mihelich, and Don Mundal for technical assistance. This work was funded in part by USDA-APHIS.

\section{Literature Cited}

1. Burks, B. D. 1955. A redefinition of the genus Zatropris, with descriptions of three new species. Proc. Ent. Soc. Wash. 57:31-37.

2. Carlson, R. B. and D. Mundal. 1990. Introduction of insects for the biological control of leafy spurge in North Dakota. North Dakota Farm Res. 47(6):7-8.

3. Lym, R. G. and K. M. Christianson. 1993. In search of leafy spurge control herbicides. North Dakota Farm Res. 49(6):31-35.

4. Lym, R. G. and C. G. Messersmith. 1993. Leafy spurge control with imazethapyr, imazaquin, quinclorac, and nicosulfuron. Res. Prog. Rep. West. Soc. Weed Sci. p. I-86-87.

5. Lym, R. G. and C. G. Messersmith. 1985. Leafy spurge control with herbicides in North Dakota: 20year summary. J. Range Manage. 38:149-154.

6. Messersmith, C. G. and R. G. Lym. 1990. Leafy spurge control: 10 years of research enhancement. North Dakota Farm Res. 47(6):3-6.

7. Nelson, Jeff. 1994. The gall midge Spurgia esculae Gagné on leafy spurge. Master's thesis. Entomology Dept., North Dakota State Univ., Fargo 58105. 76 p.

8. Pecora, P., R. W. Pemberton, M. Stazi, and G. R. Johnson. 1991. Host specificity of Spurgia esulae Gagné (Diptera: Cecidomyiidae), a gall midge introduced into the United States for control of leafy spurge (Euphorbia esula L. "complex"). Environ. Entomol. 20:282-287.

9. Rees, N. E. and P. K. Fay. 1989. Survival of leafy spurge hawk moths (Hyles euphorbiae) when larvae are exposed to 2,4-D or picloram. Weed Technol. 3:429-431.

10. Rizza, A., P. Pecora, and M. Stazi. 1982. Euphorbia spp. (leafy spurge) project. USDA-ARS Biological Control of Weeds Lab. Annu. Rep., Rome, Italy. p. 4-30.

11. Statistical Analysis System Institute. 1985. SAS User’s Guide: Statistics. Cary, NC.

12. Stougaard, R. N., R. A. Masters, and S. J. Nissen. 1992. Leafy spurge response to rate and time of application of imidazolinone herbicides. Proc. West. Soc. Weed Sci. 45:76. 